\title{
Response of a benthic microbial community to biotic disturbance
}

\author{
Robert H. Findlay*, Melanie B. Trexler, David C. White** \\ Department of Biological Sciences, Florida State University, Tallahassee, Florida 32306, USA
}

\begin{abstract}
The role of disturbance in natural microbial systems was studied by examining sediments disturbed by feeding sting rays and enteropneust worms. Biochemical measures based on the chemical components of cells were used to follow changes in the microbial community. The responses of the microbial community to feeding by rays, a mechanical disturbance to the sediments, were timedependent. Several hours after the disturbance microbial metabolic status was shifted toward synthesis of phospholipid. Microbial growth rates were greater in disturbed sediments than in ambient sediment while microbial biomass was significantly lower in the disturbed sediments. Later, microbial biomass, growth rates and metabolic status were similar in the ambient and disturbed sediments. Ingestion and subsequent defecation of sediment by enteropneust worms also profoundly affected the microbial community. The biomass and growth rates of the microbial community were significantly lower in the fresh fecal castings compared to ambient sediment while metabolic status was shifted toward phospholipid synthesis. Six hours later, microbial growth rates were greater in the fecal castings than in ambient sediments while biomass had yet to recover. Groups of ester-linked, phospholipid fatty acids, each associated with a functional group of microorganisms, varied in their response to disturbance, indicating components of the microbial community varied in their response to disturbance. An a posteriori comparison of the ambient sediments from the several study sites, each receiving differing amounts of wave and tidal action, showed that abiotic factors also influenced the microbial community structure and metabolic status. This study presents evidence that biotic and abiotic disturbances may be important factors controlling the structure of microbial communities in estuarine sediments.
\end{abstract}

\section{INTRODUCTION}

Disturbance of marine and estuarine sediments has been established as an important factor in the structuring of macrobenthic communities (e.g. Aller \& Dodge 1975, Rees et al. 1977, Woodin 1978, 1981, Kneib 1985, Oliver et al. 1985). Meiobenthic communities perceive and react to small-scale natural disturbances (Thistle 1980, Reidenauer \& Thistle 1981, Sherman et al. 1983 , Hicks 1984). Macrofaunal activity in sediments is generally perceived as stimulating microbial activity (Newell 1965, Hargrave 1970, Hylleberg 1975, Yingst \& Rhoads 1980, Aller \& Yingst 1985, Reichardt 1988). However, few studies have directly examined disturb-

\footnotetext{
Present addresses:

- Darling Marine Center and Department of Microbiology, University of Maine, Walpole, Maine 04573, USA

- Institute for Applied Microbiology, University of Tennessee, Knoxville, Tennessee 37932-2596, USA
}

ance as a controlling factor in the structuring of benthic microbial communities. A notable exception is a study by Federle et al. (1983b) that demonstrated epibenthic predators altered the benthic microbial community structure in estuarine sediments. Alongi (1985) simulated bioturbation by capitellid polychaetes and concluded that disturbance due to feeding by macrofauna had little effect on bacteria. However, Alongi's study utilized small, shallow microcosms, autoclaved sand, and daily additions of simulated detritus. In contrast, we (Findlay et al. 1990 - companion article) demonstrated in laboratory microcosms that disturbance profoundly affected sedimentary microbial communities.

Disturbance has been widely studied in numerous systems and therefore has been defined in various ways (e.g. Grime 1977, Woodin 1978). In this study, disturbance will be simply defined as any phenomenon that translocates sediment or causes a change in the chemical gradients within the sediments. Biotic disturbance will refer to those disturbances caused by 
biological agents. Physical processes, such as wave action or tidal flow, that alter chemical gradients within the sediments or translocates sediment will be considered abiotic disturbances.

This study examines the effects of 2 natural smallscale disturbances: feeding by sting rays and by enteropneust worms. Feeding rays, presumably the sting ray Dasyatis sabina (Livingston et al. 1976 , Reidenauer \& Thistle 1981, Sherman et al. 1983), dig extensive pits in search of infaunal prey. Published observations indicate that digging behavior involves rhythmic flapping of the rostrum and pectoral fins, and that sand is deposited in front of the ray (Orth 1975 , Van Blaricom 1977). The disturbance, a translocation of sediment, presumably involves abrasion, mixing and exposure of the sediments to oxygenated water. The enteropneust worm Ptychodera bahamensis is a nonselective, bulk sediment ingestor that ingests surface sediments, lives in deep ' $U$ ' shaped burrows, and deposits feces at the water-sediment interface (Dobbs \& Guckert 1988). The microbial community associated with fecal casts of the enteropneust worm would presumably have been exposed to digestive enzymes, as well as abrasion, anaerobic conditions, high alkalinity (Azariah et al. 1975) and metabolic inhibitors (Higa \& Sakemi 1983, King 1986). Results of previous experiments suggested that these 2 biotic disturbances would initially cause a decrease in microbial biomass and

A

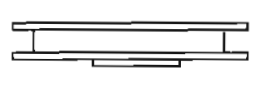

SIDE VIEY

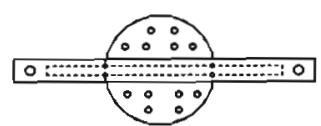

TOP VIEW
$\mathbf{B}$

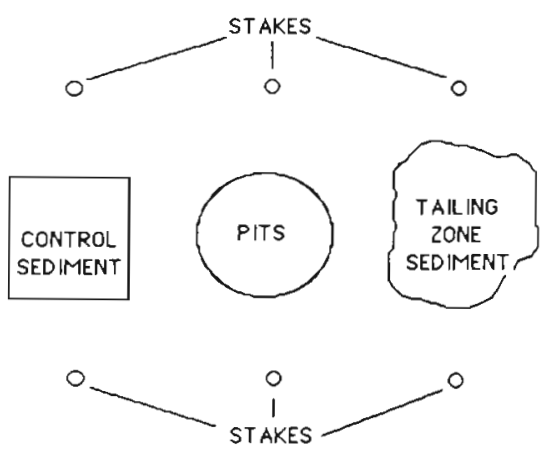

Fig. 1. Diagrammatic representation of (A) Plexiglas sampling apparatus used to sample sediments in ray feeding disturbance experiment, and (B) relative position of ambient sediments, ray feeding pits, tailings zone sediments, and stakes used to support Plexiglas sampling apparatus activity and that the community would begin to recover several hours after the disturbance (Findlay et al. 1985, 1990). A suite of biochemical assays based on the chemical components of microbial cells was used to examine this hypothesis.

\section{MATERIAL AND METHODS}

Materials. 1-( $\left.{ }^{14} \mathrm{C}\right)$-Acetate $\left(56 \mu \mathrm{Ci} \mu \mathrm{mol}^{-1}\right)$ was supplied by New England Nuclear, Boston, MA, USA. Unisil brand silicic acid was obtained from Clarkson Chemical Co., Williamsport, PA, USA. Glass-distilled solvents (Burdick and Jackson, Musekegon, WI, USA) or freshly redistilled analytical grade chloroform (Mallinkrodts, St. Louis, MO, USA) were used. Derivatizing reagents and authentic standards were purchased from Pierce Chemical Co., Rockford, IL, Aldrich Chemical Co., Milwaukee, WI, U.S. Industrial Chemical Co., Tuscola, IL, and Sigma Chemical Co., St. Louis, MO, USA. Fused silica Capillary GLC Durabond columns (DB-1) were supplied by J\&W Laboratories Inc., Rancho Cordova, CA, USA.

Study site. Ray feeding and enteropneust feeding experiments were conducted ca $1.5 \mathrm{~km}$ west of the Florida State University Marine Laboratory, Franklin County, FL, USA $\left(29^{\circ} 52^{\prime} \mathrm{N}, 84^{\circ} 31.5^{\prime} \mathrm{W}\right)$ at a sandybottom site. The slope over the site was approximately zero, and the sediment was composed of well-mixed fine sand (graphic-median diameter $=242 \mu \mathrm{m})$ (Carman \& Thistle 1985). The ray feeding pits used were ca $15 \mathrm{~m}$ from shore (MLW) in a shallow tide pool (10 to $15 \mathrm{~cm}$ deep at low tide). Enteropneust fecal mounds occurred in a broad band parallel to the shoreline ca 40 to $50 \mathrm{~m}$ from shore in the same tide pool. Both experiments were conducted in August 1983.

Experimentation. Ray feeding experiment: Pits from the feeding activity of sting rays were prevalent after early morning outgoing tides. Freshly dug pits were defined as those free of drift algae and other detritus, having steep, sharp side walls, and little or no oxidized sediment (light tan in color) on the bottom of the pit. Pits were ca $10 \mathrm{~cm}$ deep and ranged from 25 to $40 \mathrm{~cm}$ in diameter. Sediments removed from the pits were deposited in a deltoid or alluvial fan shaped mound near the anterior edge (in relationship to the activity of the ray) of the pit.

The mound or tailings zone was slightly larger in diameter than the pit. Control sediments (henceforth referred to as ambient sediments) were obtained from a quadrat starting $10 \mathrm{~cm}$ from the posterior edge of the pit. A circular, Plexiglas sampling apparatus, $25 \mathrm{~cm}$ in diameter, containing 12 regularly placed holes $(3 \mathrm{~cm}$ ID) was constructed (Fig. 1A). An 'I' beam containing 2 locating holes was added such that 2 collared stakes 
could be driven into the sediments to hold the sampling apparatus ca $2 \mathrm{~cm}$ from the sediment surface (Fig. 1A). The sampling apparatus could be removed and returned to the exact location, allowing repeated samplings. Six stakes were used for each experimental block and were placed ca $45 \mathrm{~cm}$ from the edge of the pit (Fig. 1B). Each block consisted of a pit, its associated tailings zone and ambient sediments. The 12 holes were numbered and randomly assigned a sample time and assay. Extra replicates were included in the design. Each hole was used once and if the sediment was disturbed during sampling the appropriate replacement hole was sampled. Three sampling times $2 \mathrm{~h}$ apart were used with the first being arbitrarily assigned as time $\mathrm{T}=0$. It is estimated that the first samples were obtained 3 to $5 \mathrm{~h}$ after the ray feeding activity. Three replicate pits were sampled and 3 cores $(2.5 \mathrm{~cm}$ ID) were taken for each time and treatment. One core each was utilized for lipid extraction, ${ }^{14} \mathrm{C}$-acetate incorporation into lipid, and methyl- $\left({ }^{3} \mathrm{H}\right)$-thymidine incorporation into DNA. Samples, when appropriate, were inoculated and incubated in the field. All samples were fixed in the field and transported on ice to the laboratory for processing. In all cases the top $2 \mathrm{~cm}$ of sediment were analyzed.

Enteropneust feeding experiment: The mounds of sediment formed by the fecal castings of an enteropneust worm (Ptychodera bahamensis) were easily observed and manipulated at low tide. To obtain fecal castings of known age, six $3 \times 3 \mathrm{~m}$ quadrats were set up, all castings within the quadrats mapped and the castings removed by sucking the sediment into a large bore pipet. The sites of the former castings were monitored for the appearance of fresh fecal material. When fresh castings were observed the time of appearance was recorded and a metal plate $(\mathrm{ca} 5 \times 10 \mathrm{~cm}$ ) was inserted into the sediment at a $45^{\circ}$ angle to block any further addition of fecal material. The mounds were numbered in their order of appearance and assigned a time and assay using a random number table. Fecal castings were sampled upon appearance $(\mathrm{T}=0)$ and 2 , 4 , and $6 \mathrm{~h}$ after appearance. Six replicate samples per assay and time were used. Ambient sediments utilized as control samples were taken $15 \mathrm{~cm}$ from the mound in a randomly determined compass direction. All samples were taken using $2.5 \mathrm{~cm}$ ID polystyrene cores and the top $1 \mathrm{~cm}$ of sediment was analyzed. Samples, when appropriate, were inoculated and incubated in the field. All samples were fixed at the study site and returned to the main laboratory on ice for further processing.

Comparison of ambient sediments. The sites of the various experiments received different levels of abiotic disturbances. The site of the enteropneust experiments was close to the bar that defined the tide pool used in these experiments and received substantial tidal flow and wave action during most of the tidal cycle. The site of the ray feeding experiments was closer to shore and was less influenced by both tidal flow and wave action. An additional study site (data presented in Findlay et al. 1990) received substantial wave action, but little tidal flow. An a posteriori comparison of these sediments as well as the sediments maintained in laboratory microcosms for $5 \mathrm{~d}$ (Findlay et al. 1990) was performed to help elucidate the role of abiotic disturbance in structuring the benthic microbial community.

Analysis. An integrated biochemical approach detailed in the companion study (Findlay et al. 1990) was used to characterize the benthic microbial community. Three measures of microbial biomass were employed: (1) total ester-linked, phospholipid fatty acids (TPLFA), (2) total phospholipid phosphate (LPO4), and (3) total muramic acid (MA). Microbial growth rates were measured by the rate of incorporation of ${ }^{3} \mathrm{H}$-thymidine into DNA per unit biomass and the rate of incorporation of ${ }^{14} \mathrm{C}$-acetate into phospholipid fatty acids per unit biomass. The abundance and mole-percent values of the individual ester-linked, phospholipid fatty acids (PLFA) were utilized to determine microbial community structure. Short-term (minutes) metabolic status was assayed using the ratio of the relative rate of acetate incorporation into phospholipid to the relative rate of acetate incorporation into poly-beta-hydroxyalkanoates (14CPLFA/ 14CPHA). Long term (hours) metabolic status was determined by the concentration of poly-beta-hydroxyalkanoates (PHA). The concentration of microeucaryotic triglyceride was determined as triglyceride-bound glycerol (GLY).

Experimental design and statistics. Ray feeding experiment: The design of the ray feeding disturbance experiment was a treatments $\times$ blocks design with time and type of disturbed sediment as treatments. Analysis of variance was performed using the ANOVA subprogram available in Statistical Package for the Social Sciences (SPSS, Inc., Chicago, IL, USA). Data were first tested for time $\times$ disturbance interactive effects. If no significant interactive effects were found, data were tested for time effects and disturbance effects. All data were natural log transformed before statistical analysis. When significant time $\times$ treatment interactions occurred, treatments at a single time were compared in an a posteriori test using the Bonferroni procedure for multiple contrasts of treatment means (Neter et al. 1985)

Enteropneust feeding experiment: A matched pair design was utilized for the enteropneust feeding experiment with the data being expressed as the difference between the fecal casts and the ambient sediments (i.e. difference ${ }_{i}\left(d_{i}\right)=$ treatment $_{1}\left(t_{i}\right)-$ control $_{1}\left(c_{1}\right)$ for 
all i). One-way ANOVA with time serving as the independent variable was performed using the ONE-WAY subprogram available in SPSS. An orthogonal contrast was utilized to test for a linear trend over time. If significant differences with time were noted in any $d_{i}$ then the control data were analyzed for significant differences and linear trends with time to ensure that changes in $d_{i}$ were not generated by a change in the ambient sediments. All data were natural log transformed before generation of $\mathrm{d}_{i}$. If significant heteroscedasticity of variance of $d_{i}$ was found with either the Bartlett's-Box F test or the Cochran's C test, nonparametric statistics based on the Wilcoxon sign ranks test were used to analyze the data. The sign and magnitude (relative to the variance) of the ' $d$ ' statistic indicated if there was a significant treatment effect (Brown \& Hollander 1977). The mean differences at time $T=0$ were used to test for significant treatment effects. A ' $t$ ' test for matched pairs was used to test the null hypothesis $\mathrm{H}_{\mathrm{o}}$ : $\mathrm{d}=0$.

\section{RESULTS}

\section{Ray feeding experiment}

Short-term metabolic status, measured using the ratio $14 \mathrm{CPLFA} / 14 \mathrm{CPHA}$, showed a significant time $\times$ treatment interactive effect (Table $1_{i}$ Fig. 2). There was a general trend toward decreasing ratios in each treatment over time. Comparison of 14CPLFA/14CPHA at time $\mathrm{T}=0$ and $\mathrm{T}=2 \mathrm{~h}$ showed pit sediments and tailings zone sediments had significantly higher ratios than ambient sediments. Similar comparison at time $\mathrm{T}=4 \mathrm{~h}$ showed no significant differences between means.

Microbial growth rates also showed significant treatment $\times$ time interactive effects (Table 1; Fig. 2) Ambient sediments showed little change in growth rates with time. Pit and tailings zone sediments showed significantly greater rates of growth at time $\mathrm{T}=2 \mathrm{~h}$ when compared to ambient sediments. Similar comparisons revealed no significant difference at time $\mathrm{T}=$ 0 and $\mathrm{T}=4 \mathrm{~h}$.

Measures of microbial biomass showed significant treatment and time effects. All measures of microbial biomass increased with time (Table 2; Fig. 2). The ambient sediments showed the lowest percent increase in biomass and the pit sediments the greatest percent increase in biomass. A posteriori tests for differences at individual times indicated that for all 3 measures, the pit and tailings zone sediments had significantly less microbial biomass than ambient sediments at times $T=$ 0 and $\mathrm{T}=2 \mathrm{~h}$, while at time $\mathrm{T}=4 \mathrm{~h}$ there were no significant differences in microbial biomass.

The quantity of procaryotic and microeucaryotic lipid storage materials, measured as PHA and triglyceride glycerol, showed significant treatment effects. Both the pit and tailings zone sediments contained ca $50 \%$ less PHA and triglyceride glycerol than ambient sediments throughout the experiment (Table 2)

Ester-linked, phospholipid fatty acids were analyzed using the functional-group approach outlined in Findlay et al. (1990). Briefly, phospholipid fatty acids were

Table 1. Effect of sting ray feeding on microbial activity and short-term metabolic status. Data are given as means \pm SD, $\mathrm{n}=3$. Time is from start of the experiment. Ray feeding was unobserved, but was estimated to have occurred 3 to $5 \mathrm{~h}$ before start of experiment. Significant differences between treatment means at single times were calculated using the Bonferroni procedure for multiple contrasts of means. Treatment means $(A=$ ambient sediments, $T=$ tailings zone sediments, $P=$ pit sediments) decrease from left to right and means connected by a line are not significantly different at a family-error rate of $p=0.05$

\begin{tabular}{|c|c|c|c|c|c|}
\hline $\begin{array}{l}\text { Time } \\
\text { (h) }\end{array}$ & $\begin{array}{l}\text { Ambient } \\
\text { sediments }\end{array}$ & $\begin{array}{l}\text { Pit } \\
\text { sediments }\end{array}$ & $\begin{array}{l}\text { Tailings zone } \\
\text { sediments }\end{array}$ & ANOVA & $\begin{array}{l}\text { Comparison at } \\
\text { individual times }\end{array}$ \\
\hline \multicolumn{6}{|c|}{ Ratio dpm's PLFA/dpm's PHA } \\
\hline 0 & $0.42 \pm 0.10$ & $0.63 \pm 0.13$ & $0.75 \pm 0.10$ & Time $\times$ Treatment & Time $=0 \mathrm{IP} \mathrm{A}$ \\
\hline 2 & $0.39 \pm 0.06$ & $0.56 \pm 0.15$ & $0.46 \pm 0.09$ & interaction & Time $=2 \mathrm{P} \mathrm{T} A$ \\
\hline 4 & $0.36 \pm 0.07$ & $0.44 \pm 0.11$ & $0.49 \pm 0.06$ & $p<0.05$ & Time $=4 \overline{\mathrm{TP}} \overline{\mathrm{A}}$ \\
\hline \multicolumn{6}{|c|}{$\begin{array}{l}\text { pmoles thymidine incorporated into DNA } \\
\text { min }^{-1} \mu \mathrm{mol}^{-1} \text { phospholipid phosphate }\end{array}$} \\
\hline 0 & $0.84 \pm 0.45$ & $1.61 \pm 0.51$ & $1.99 \pm 1.31$ & Time $\times$ Treatment & Time $=0 \mathrm{TPA}$ \\
\hline 2 & $1.20 \pm 0.03$ & $2.88 \pm 1.52$ & $1.95 \pm 0.15$ & interaction & Time $=2 \underline{P} \underline{A}$ \\
\hline 4 & $0.93 \pm 0.11$ & $1.01 \pm 0.61$ & $1.12 \pm 0.60$ & $p<0.05$ & Time $=4 \mathrm{IPA}$ \\
\hline \multicolumn{6}{|c|}{$\begin{array}{l}\text { pmoles acetate incorporated into phospholipid } \\
\text { min }^{-1} \mu \mathrm{mol}^{-1} \text { phospholipid phosphate }\end{array}$} \\
\hline 0 & $46.5 \pm 34.0$ & $121.5 \pm 7.61$ & $115.0 \pm 41.1$ & Time $\times$ Treatment & Time $=0 \underline{P} \mathrm{TA}$ \\
\hline 2 & $42.2 \pm 5.5$ & $249.0 \pm 45.5$ & $203.8 \pm 72.0$ & interaction & Time $=2 \mathrm{P} \mathrm{TA}$ \\
\hline 4 & $42.2 \pm 12.2$ & $49.2 \pm 14.9$ & $83.2 \pm 27.0$ & $p<0.05$ & Time $=4 \mathrm{TPA}$ \\
\hline
\end{tabular}



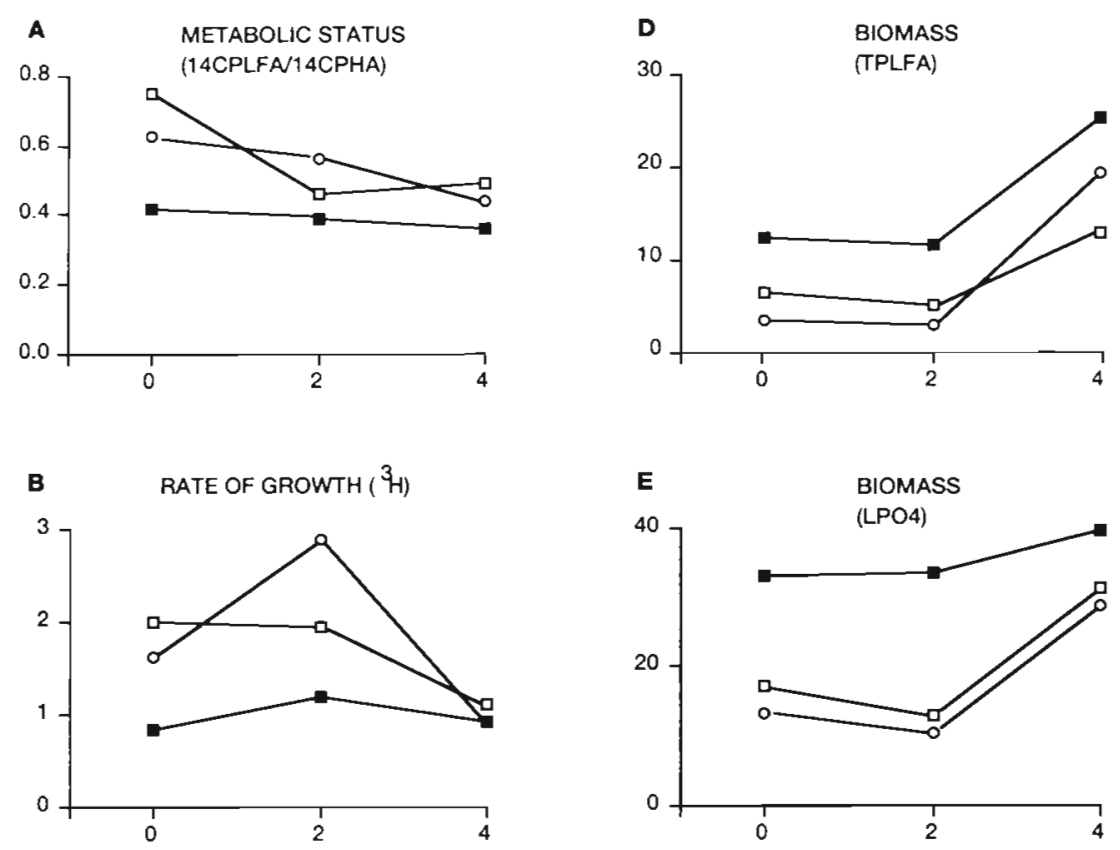

Fig. 2. Effect of ray feeding on (A) shortterm metabolic status, $(B, C)$ growth rates and $(D, E, F)$ biomass of an estuarine sedimentary microbial community. (a) Ambient sediment; $(\square)$ tailings zone sediments; (0) sediments from the bottom of the ray feeding pits. Zero hours represents the start of the sampling period. Ray feeding was unobserved, but was estimated to have occurred 3 to $5 \mathrm{~h}$ before the start of the experiment. Units, standard deviations and statistical analyses are given in Tables 1 and 2
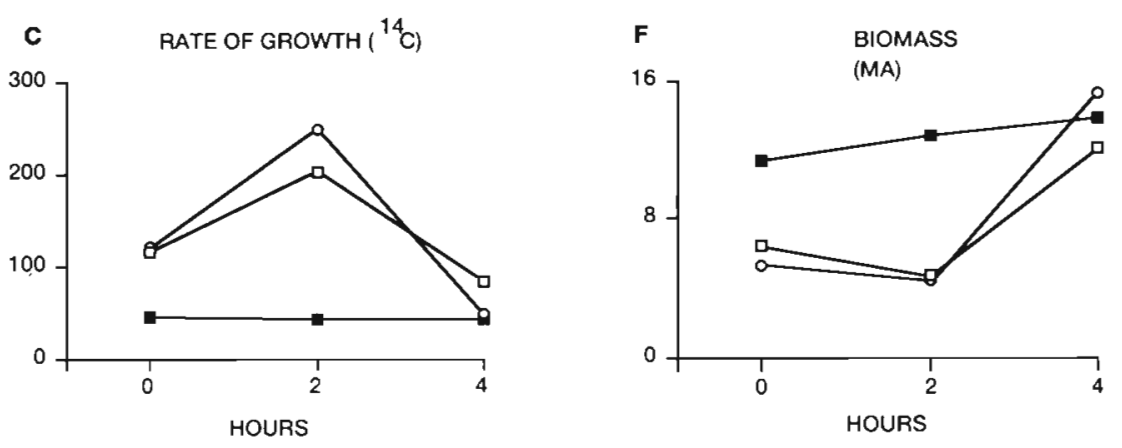

found to cluster into 4 distinct groups and these clusters were assigned to functional groups of microorganisms. They are: Cluster 1, microeucaryotes; Cluster 2, aerobic microorganisms; Cluster 3, Gram-positive procaryotes and some anaerobic bacteria; Cluster 4 , sulfate-reducing bacteria and other anaerobic procaryotes. Cluster 1 fatty acids were not found at this site. Five Cluster $2(16: 1 \omega 7 \mathrm{c}, 17: 1 \omega 9,18: 1 \omega 7 \mathrm{c}, 18: 1 \omega 9 \mathrm{c}$, 18:2w6) fatty acids were present in these sediments. The 4 monoenoic fatty acids of this group showed similar patterns of change (Table 3; Fig. 3). The abundance of these fatty acids changed little over time in the ambient sediments but increased at time $\mathrm{T}=4 \mathrm{~h}$ in pit and tailings zone sediments. These increases were such that at time $\mathrm{T}=4 \mathrm{~h}$ mean abundances were greater in pit and tailings zone sediments than in control sediments. ANOVA showed no significant interaction, time, or treatment effects for $16: 1 \omega 7 \mathrm{C}$ or $18: 1 \omega 9 \mathrm{C}$. The fatty acid 17:169 showed significant time effects while $18: 1 \omega 7 \mathrm{C}$ showed significant treatment effects. The pattern of changes in the mole-percent values were also similar for the 4 fatty acids. Mole-percent values for pit and tailings zone sediments were unchanged with time, while control sediments had mole-percent values that declined by an average of $54 \%$. ANOVA showed no interactive, time, or treatment effects. Fatty acid 18:206 showed a different pattern. ANOVA indicated a significant time effect as abundance of this fatty acid increased in all treatment groups. Mole-percent values for 18:2w6 showed no significant differences with time or treatment.

The abundance of the Cluster 3 fatty acids, except $16: 1 \omega 13 t$, showed significant increases with time (Table 3 ; Fig. 3). These increases were greatest in ambient sediments and intermediate in the pit sediments. The tailings zone sediments showed the smallest increases. The concentration of 16:1w13t showed no significant differences with time or treatment. Molepercent values for all Cluster 3 fatty acids showed no significant differences with either time or treatment.

The abundance of all Cluster 4 fatty acids showed both significant time and treatment effects (Table 3 ; 
Table 2. Effect of sting ray feeding on microbial biomass and long-term metabolic status. Data are given as means $\pm \mathrm{SD}, \mathrm{n}=3$. Time is from start of the experiment. Ray feeding was unobserved, but was estimated to have occurred 3 to $5 \mathrm{~h}$ before start of experiment. Significant differences between treatment means at single times were calculated using the Bonferroni procedure for multiple contrasts of means. Treatment means $(\mathrm{A}=$ ambient sediments, $\mathrm{T}=$ tailings zone sediments, $\mathrm{P}=$ pit sediments) decrease from left to right and means connected by a line are not significantly different at a family-error rate of $p=0.05$ nd: analysis was not done as there were no multiple time and treatment effects

\begin{tabular}{|c|c|c|c|c|c|}
\hline Time & $\begin{array}{l}\text { Ambient } \\
\text { sediments }\end{array}$ & $\begin{array}{l}\text { Pit } \\
\text { sediments }\end{array}$ & $\begin{array}{l}\text { Tailings zone } \\
\text { sediments }\end{array}$ & ANOVA & $\begin{array}{l}\text { Comparison at } \\
\text { individual times }\end{array}$ \\
\hline \multicolumn{6}{|c|}{ umoles total phospholipid fatty acids } \\
\hline 0 & $12.4 \pm 1.0$ & $3.4 \pm 1.4$ & $6.6 \pm 2.4$ & Time effect & Time $=0 \mathrm{~A} \mathrm{~T} \mathrm{P}$ \\
\hline 2 & $11.5 \pm 4.1$ & $3.0 \pm 1.3$ & $5.1 \pm 1.3$ & $p<0.05$ & Time $=2 \mathrm{~A}$ \\
\hline \multirow[t]{2}{*}{4} & $25.5 \pm 6.7$ & $19.4 \pm 13.1$ & $13.0 \pm 11.4$ & $\begin{array}{l}\text { Treatment effect } \\
p<0.025\end{array}$ & Time $=4 \mathrm{~A} T$ \\
\hline & \multicolumn{3}{|c|}{ umoles phospholipid phosphate } & & \\
\hline 0 & $33.1 \pm 6.5$ & $13.5 \pm 5.1$ & $17.3 \pm 0.8$ & Time effect & Time $=0 \underline{\mathrm{A}} \underline{\mathrm{T}} \mathrm{P}$ \\
\hline 2 & $33.6 \pm 7.5$ & $10.3 \pm 3.9$ & $13.0 \pm 2.0$ & $p<0.01$ & Time $=2 \mathrm{~A} \mathrm{TP}$ \\
\hline \multirow[t]{2}{*}{4} & $39.7 \pm 7.4$ & $29.0 \pm 8.8$ & $31.5 \pm 14.8$ & $\begin{array}{l}\text { Treatment effect } \\
\qquad<<0.01\end{array}$ & Time $=4 \mathrm{~A}$ \\
\hline & \multicolumn{3}{|c|}{ nmoles muramic acid } & & \\
\hline 0 & $11.4 \pm 1.4$ & $5.3 \pm 0.8$ & $6.5 \pm 2.8$ & Time effect & Time $=0 \underline{\mathrm{A}} \underline{\mathrm{T}} \mathrm{P}$ \\
\hline 2 & $12.9 \pm 4.2$ & $4.5 \pm 1.3$ & $4.8 \pm 1.2$ & $p<0.005$ & Time $=2 \frac{\mathrm{A}}{\mathrm{A} P}$ \\
\hline \multirow[t]{2}{*}{4} & $13.9 \pm 1.5$ & $15.3 \pm 4.6$ & $12.1 \pm 1.9$ & $\begin{array}{l}\text { Treatment effect } \\
\qquad p<0.005\end{array}$ & Time $=4 \underline{\mathrm{P} T}$ \\
\hline & \multicolumn{3}{|c|}{ nmoles PHA } & & \\
\hline 0 & $6.52 \pm 1.00$ & $1.98 \pm 1.11$ & $1.57 \pm 2.30$ & Treatment effect & nd \\
\hline 2 & $8.46 \pm 2.09$ & $1.50 \pm 0.80$ & $0.77 \pm 1.33$ & $p<0.005$ & \\
\hline \multirow[t]{2}{*}{4} & $6.04 \pm 1.05$ & $1.28 \pm 1.58$ & $2.74 \pm 1.60$ & & \\
\hline & \multicolumn{3}{|c|}{ pmoles triglyceride glycerol } & & \\
\hline 0 & $26.6 \pm 3.5$ & $12.9 \pm 7.4$ & $15.9 \pm 3.5$ & Treatment effect & nd \\
\hline 2 & $31.6 \pm 6.8$ & $18.0 \pm 9.3$ & $14.4 \pm 8.4$ & $p<0.005$ & \\
\hline 4 & $33.3 \pm 6.0$ & $22.5 \pm 10.5$ & $21.8 \pm 15.8$ & & \\
\hline
\end{tabular}

Fig. 3). Abundances were greater in the ambient sediments than in pit or tailings zone sediments. Abundances increased in all treatments with time. Mole-percent values showed no significant differences with either time or treatment.

\section{Enteropneust feeding experiment}

Short-term metabolic status, measured as the average differences for 14CPLFA/14CPHA, showed signif cant non-homogeneity of variance by both Bartlett'sBox F and Cochran's $C$ tests before and after natural $\log$ conversion. These data were analyzed using a nonparametric analog to 1-way ANOVA based on the Wilcoxon sign ranks test (Hollander \& Wolfe 1973). No significant differences between times were observed. The average differences were significantly greater than zero at time $\mathrm{T}=0$ using the Wilcoxon sign ranks test (Table 4; Fig. 4).

The average differences for microbial growth rates showed significant changes and increasing linear trends with time (Table 4 ; Fig. 4). Comparison of means show that average differences for the rate of acetate incorporation into phospholipid at time $\mathrm{T}=0$ were significantly lower than the average differences at times $T=2 \mathrm{~h}$ and $\mathrm{T}=4 \mathrm{~h}$, which in turn were significantly lower than the values at time $\mathrm{T}=6 \mathrm{~h}$. Similar comparisons for thymidine incorporation into DNA showed average differences for times $\mathrm{T}=0, \mathrm{~T}=2 \mathrm{~h}$, and $T=4 \mathrm{~h}$ were significantly lower than the values for time $T=6 \mathrm{~h}$. The average differences, for both measures, were significantly less than zero at time $\mathrm{T}=$ 0 and significantly greater than zero at time $T=6 \mathrm{~h}$ (Table 4; Fig. 4). Subsequent ANOVA of the ambient sediments showed no significant differences or linear trends with time (data not shown).

The average differences for the 3 measures of microbial biomass showed no significant changes over the $6 \mathrm{~h}$ of the experiment. The average differences for phospholipid phosphate were not significantly different from zero at time $T=0$, but was significantly less than zero at time $\mathrm{T}=2 \mathrm{~h}$. The average differences for muramic acid and total ester-linked, phospholipid fatty acids were significantly less than zero at time $\mathrm{T}=0$ (Table 5) 


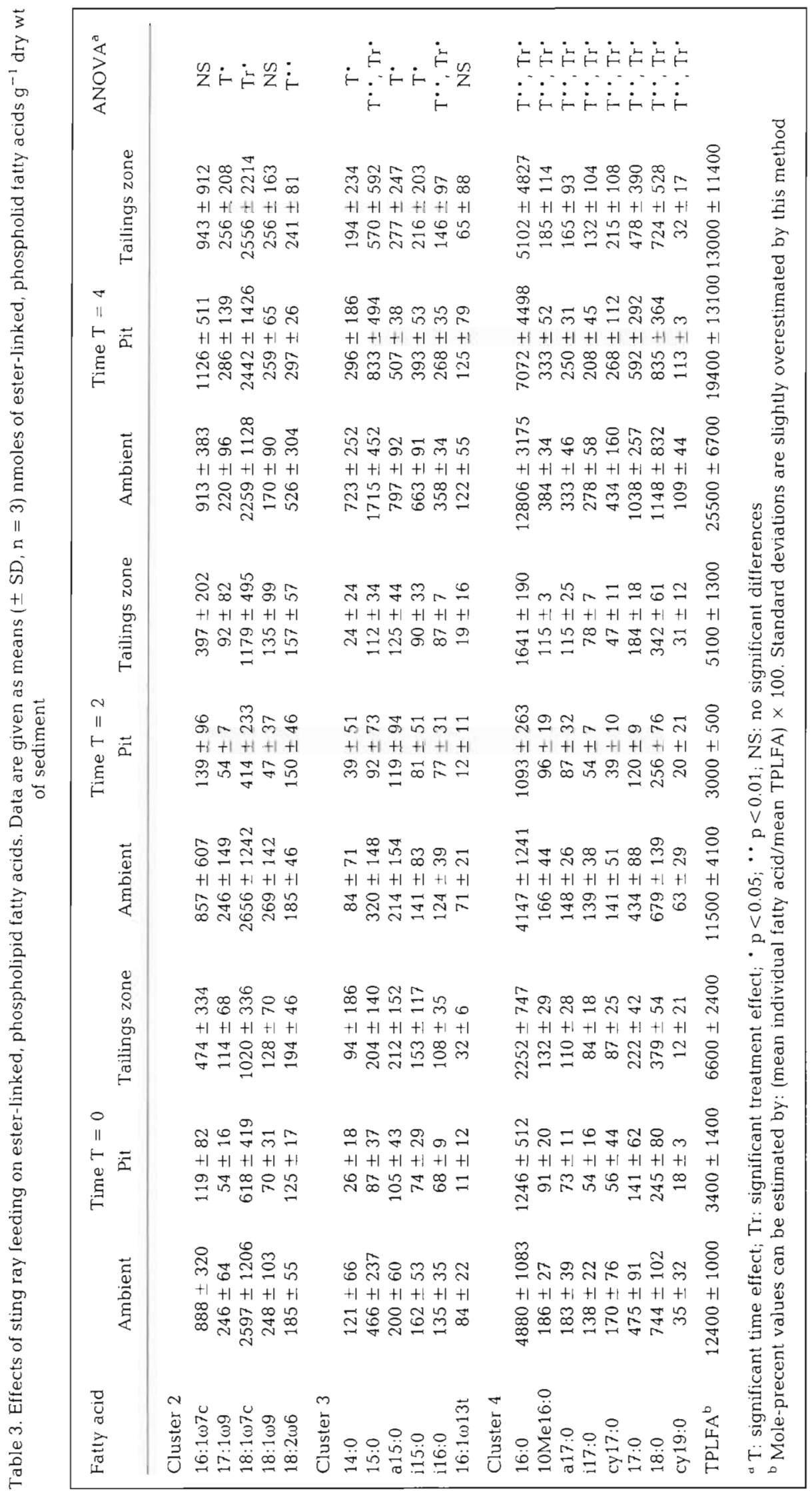



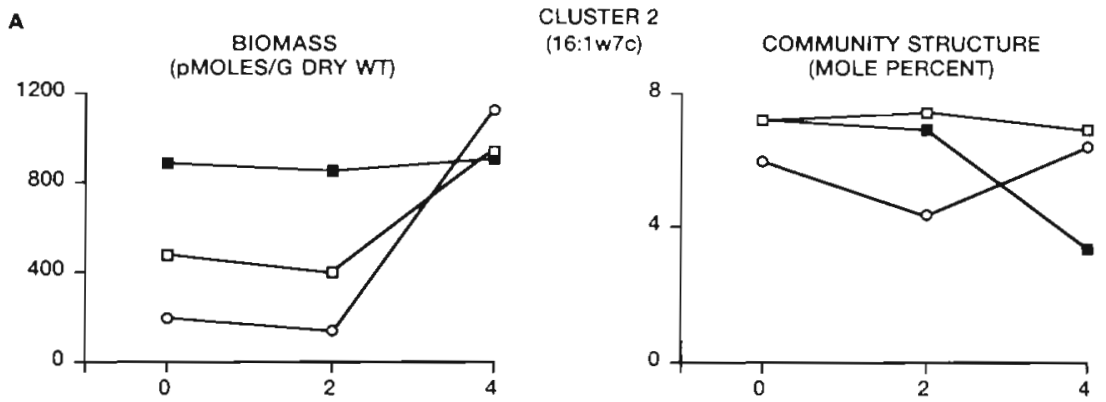

c
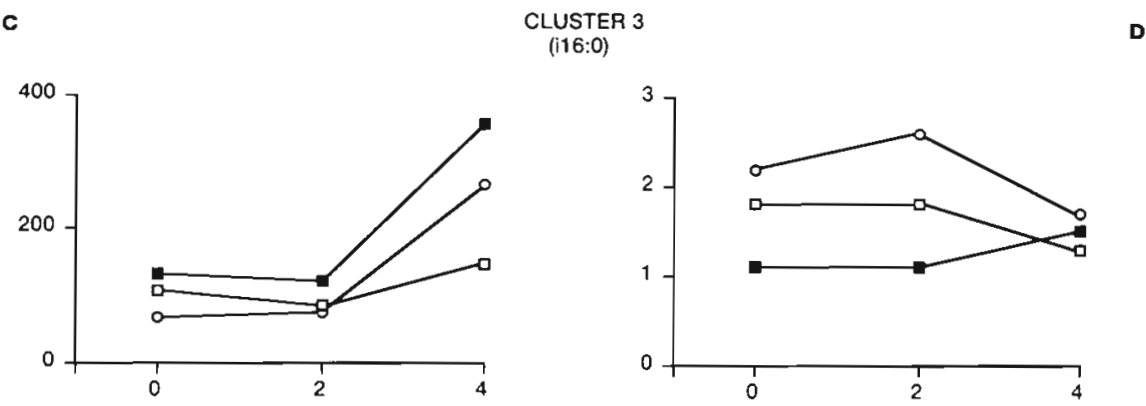

E CLUSTER 4 (10Me16:0)
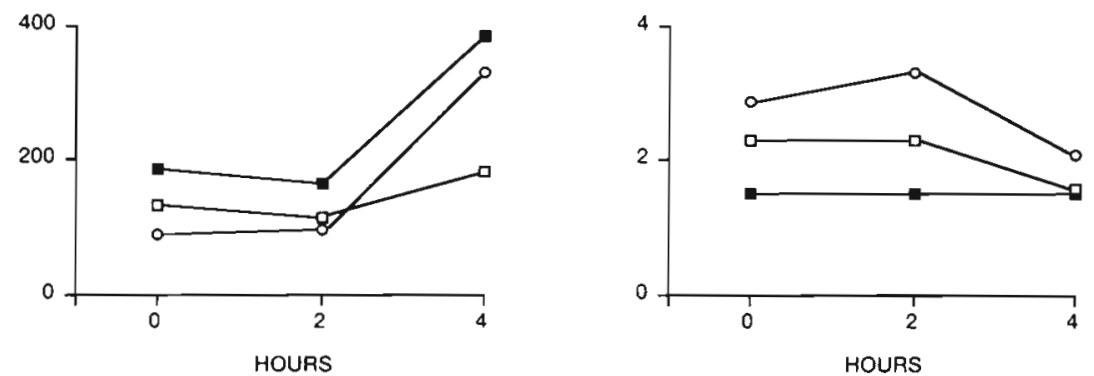

Fig. 3. Examples of the effect of ray feeding on abundance and molepercent values of $(A, B)$ Cluster 2, (C, D) Cluster 3 , and (E, F) Cluster 4 phospholipid-bound fatty acids. Symbols and sampling as in Fig. 2 Standard deviations and statistical analyses of the abundance data are given in Table 3

Table 4. Effect of enteropneust feeding on microbial activity and short-term metabolic status. Data given as mean difference \pm $\mathrm{SD}, \mathrm{n}=6$. Difference calculated as Treatment - Ambient $_{\mathrm{i}}$. Negative values indicate a decrease in microbial activity with enteropneust feeding and positive values indicate an increase in microbial activity with enteropneust feeding. ANOVA: 1 -way analysis of variance to determine time effect. Significant differences between times were determined using the Student-NewmanKeuls procedure. Means are listed as decreasing from left to right and means not connected by a line are significantly different at a family-error rate of $p=0.05$. An orthogonal contrast was utilized to test for a linear trend with time. Two-tailed t-test for matched pairs was used to test for treatment effects at individual times. Significant heteroscedasticity of variance was found for the ratio ${ }^{14} \mathrm{CPLFA} /{ }^{14} \mathrm{CPHA}$ after natural $\log$ transformation and the nonparametric Wilcoxon sign ranks test was used to analyze the data. Tr: treatment sediments (the fecal casts); A: ambient sediments

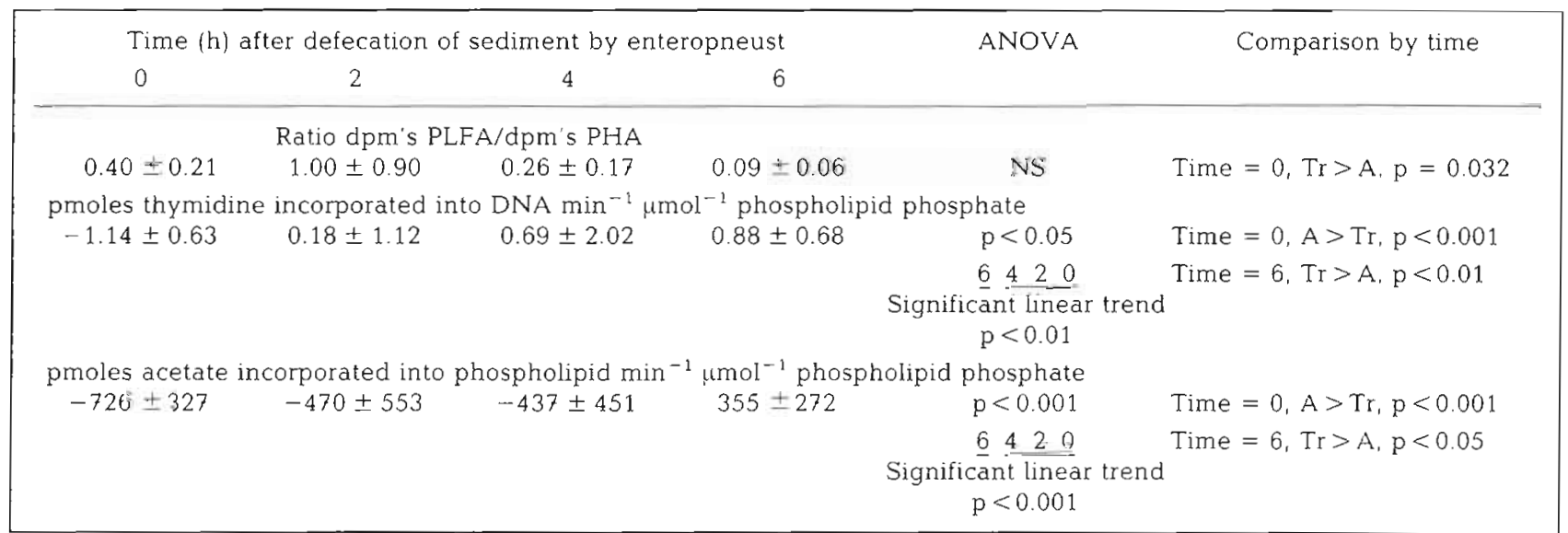




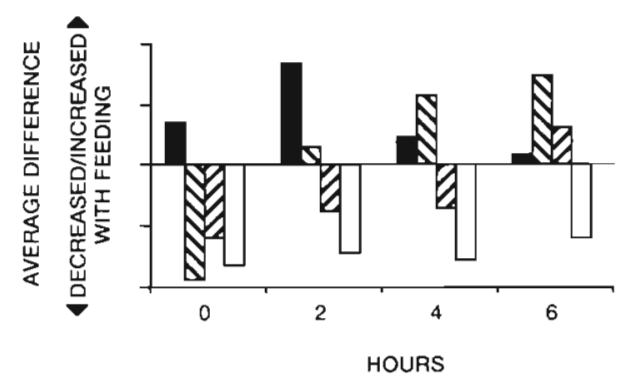

Fig. 4. Effect of enteropneust feeding on the average differences (fecal casts - ambient sediments) in short-term metabolic status (black bars: ratio 14CPLFA/14CPHA, range of y-axis, -1.2 to 1.2 ), rates of growth (left hatched bars: ${ }^{3} \mathrm{H}$ thymidine into DNA, range of y-axis, -1.2 to 1.2 pmol thymidine $\mathrm{min}^{-1} \mu \mathrm{mol}^{-1} \mathrm{LPO} 4$; right hatched bars: ${ }^{14} \mathrm{C}$-acetate into phospholipid, range of $y$-axis, -1.2 to $1.2 \mathrm{nmol}$ acetate $\min ^{-1} \mu \mathrm{mol}^{-1}$ LPO4) and microbial biomass (open bars: TPLFA, range of $y$-axis, -30 to $30 \mu \mathrm{mol}$ ) of an estuarine sedimentary microbial community. Standard deviations and statistical analyses are given in Tables 4 and 5

The quantity of procaryotic and microeucaryotic lipid storage materials, measured as the average differences of PHA and GLY, respectively, showed no significant changes with time (Table 5). The average differences for PHA and GLY at time $\mathrm{T}=0$ were significantly less than zero.

In all cases, the average differences for the abundance of the individual fatty acids and the average differences for their mole-percent values showed no significant changes with time, therefore only data from time $\mathrm{T}=0$ will be given (Table 6 ). The average percentage decrease at time $T=0$ in the abundance of the individual ester-linked, phospholipid fatty acids ranged from 46 to $90 \%$.
Two Cluster 1 fatty acids were present (20:4w6 and $20: 5 \omega 3)$ and their average differences in abundance were significantly less than zero at $\mathrm{T}=0$. The average difference for mole-percent values was not significantly different from zero at time $\mathrm{T}=0$.

Five Cluster 2 fatty acids were present and for each fatty acid the average difference in abundance was significantly lower than zero at time $\mathrm{T}=0$. Average differences for mole-percent values were not significantly different from zero at times $\mathrm{T}=0$.

Five Cluster 3 fatty acids were quantified. Average differences in abundance for 14:0, a15:0, i15:0 and i16:0 were not significantly different from zero at time $\mathrm{T}=0$. For 15:0, average differences in pmoles per $\mathrm{g}$ dry weight of sediment were significantly less than zero at time $\mathrm{T}=0$. Average differences for mole-percent values for i16:0 were significantly greater than zero.

Average differences in abundance for all Cluster 4 fatty acids save one were significantly less than zero at time $\mathrm{T}=0$; the average difference for fatty acid cy 19:0 (Table 6) was not significantly different from zero. The average differences for mole-percent values for 10Me16:0 were significantly greater than zero at time $\mathrm{T}=0$. The average differences for mole-percent values were not significantly different from zero for the other Cluster 4 fatty acids.

\section{Comparison of ambient sediments}

Microbial biomass, measured as total ester-linked, phospholipid fatty acids, was greatest in the ambient sediments from the site receiving the greatest wave

Table 5. Effect of enteropneust feeding on microbial biomass and long-term metabolic status. Data given as mean difference \pm $\mathrm{SD}, \mathrm{n}=6$. Difference calculated as Treatment $\mathrm{T}_{\mathrm{i}}-$ Ambient $_{\mathrm{i}}$. Negative values indicate a decrease with enteropneust feeding ANOVA: 1-way analysis of variance to determine changes with time in microbial biomass or metabolic status following enteropneust feeding. Two-tailed t-test for matched pairs used to test for effects of enteropneust feeding at time $\mathrm{T}=0$. Tr . treatment sediments (the fecal casts); A: ambient sediments

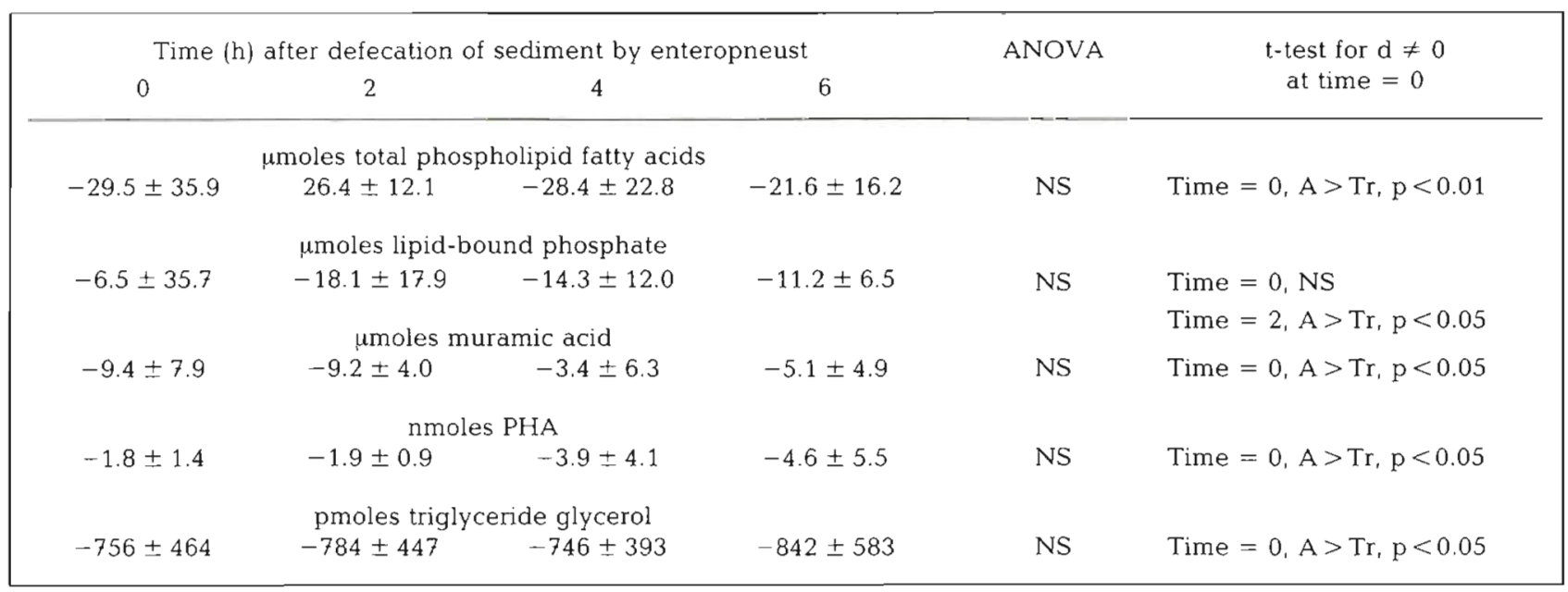


Table 6. Effect of enteropneust feeding on microbial community structure. Abundance data given as mean difference in pmoles fatty acid $\pm S D, n=6$. Difference calculated as Treatment $t_{i}-$ Ambient $_{\mathrm{i}}$. Negative values indicate a decrease with enteropneust feeding. Mole percent data given as mean difference in mole percent $\pm \mathrm{SD}, \mathrm{n}=6$. Mole percent calculated as (pmoles fatty acid/ pmoles TPLFA) $\times 100$, difference calculated as Treatment $t_{1}-$ Ambient $_{i}$. Negative values indicate a decrease with enteropneust feeding. Two-tailed t-test for matched pairs used to test for effects of enteropneust feeding at time $T=0$. Tr: treatment sediments (the fecal casts); A: ambient sediments

\begin{tabular}{|c|c|c|c|c|}
\hline Fatty acid & Abundance & Mole percent & $\begin{array}{l}\text { t-test for } d \neq 0 \\
\text { (abundance) }\end{array}$ & $\begin{array}{l}\mathrm{t} \text {-test for } \mathrm{d} \neq 0 \\
\text { (mole percent) }\end{array}$ \\
\hline \multicolumn{5}{|l|}{ Group 1} \\
\hline $\begin{array}{l}20: 4 \omega 6 \\
20: 5 \omega 3\end{array}$ & $\begin{array}{l}-788 \pm 396 \\
-607 \pm 207\end{array}$ & $\begin{array}{r}0.08 \pm 2.66 \\
-0.21 \pm 1.84\end{array}$ & $\begin{array}{l}A>T r, p<0.05 \\
A>T r, p<0.05\end{array}$ & $\begin{array}{l}\text { NS } \\
\text { NS }\end{array}$ \\
\hline \multicolumn{5}{|l|}{ Group 2} \\
\hline $\begin{array}{l}16: 1 \omega 7 \\
17: 1 \omega 9 \\
18: 1 \omega 7 \\
18: 1 \omega 9 \\
18: 2 \omega 6\end{array}$ & $\begin{array}{c}-2714 \pm 3121 \\
-516 \pm 539 \\
-9069 \pm 12076 \\
-449 \pm 372 \\
-243 \pm 255\end{array}$ & $\begin{array}{r}-0.72 \pm 2.01 \\
-0.38 \pm 0.50 \\
-3.05 \pm 9.08 \\
-0.06 \pm 1.02 \\
0.62 \pm 0.50\end{array}$ & $\begin{array}{l}A>\operatorname{Tr}, p<0.01 \\
A>T r, p<0.01 \\
A>T r, p<0.01 \\
A>\operatorname{Tr}, p<0.001 \\
A>T r, p<0.05\end{array}$ & $\begin{array}{l}\text { NS } \\
\text { NS } \\
\text { NS } \\
\text { NS } \\
\text { NS }\end{array}$ \\
\hline \multicolumn{5}{|l|}{ Group 3} \\
\hline $\begin{array}{l}14: 0 \\
15: 0 \\
\text { a } 15: 0 \\
i 15: 0 \\
i 16: 0\end{array}$ & $\begin{array}{l}-642 \pm 942 \\
-880 \pm 1023 \\
-228 \pm 387 \\
-246 \pm 329 \\
-37 \pm 141\end{array}$ & $\begin{array}{r}0.37 \pm 1.62 \\
-0.08 \pm 1.40 \\
1.90 \pm 2.45 \\
0.80 \pm 1.14 \\
1.20 \pm 1.84\end{array}$ & $\begin{array}{c}\text { NS } \\
A>\operatorname{Tr}, p<0.05 \\
\text { NS } \\
\text { NS } \\
\text { NS }\end{array}$ & $\begin{array}{c}\text { NS } \\
\text { NS } \\
\text { NS } \\
\text { NS } \\
\operatorname{Tr}>A, p<0.05\end{array}$ \\
\hline \multicolumn{5}{|l|}{ Group 4} \\
\hline $\begin{array}{l}16: 0 \\
10 \mathrm{Me} 16: 0 \\
17: 0 \\
\text { a17:0 } \\
\text { cy17:0 } \\
\text { i17:0 } \\
18: 0 \\
\text { cy19:0 }\end{array}$ & $\begin{aligned}-9764 & \pm 11784 \\
-103 & \pm 94 \\
-768 & \pm 806 \\
-85 & \pm 72 \\
-321 & \pm 459 \\
-200 & \pm 204 \\
-970 & \pm 1062 \\
-348 & \pm 635\end{aligned}$ & $\begin{array}{r}-1.20 \pm 4.84 \\
0.53 \pm 0.56 \\
0.32 \pm 2.32 \\
0.29 \pm 0.36 \\
0.13 \pm 0.48 \\
-0.29 \pm 0.78 \\
0.78 \pm 2.90 \\
-0.24 \pm 0.46\end{array}$ & $\begin{array}{c}A>T r, p<0.01 \\
A>\operatorname{Tr}, p<0.025 \\
A>\operatorname{Tr}, p<0.025 \\
A>\operatorname{Tr}, p<0.025 \\
A>\operatorname{Tr}, p<0.05 \\
A>\operatorname{Tr}, p<0.01 \\
A>\operatorname{Tr}, p<0.025 \\
\quad N S\end{array}$ & $\begin{array}{c}\text { NS } \\
\operatorname{Tr}>\text { A, p }<0.05 \\
\text { NS } \\
\text { NS } \\
\text { NS } \\
\text { NS } \\
\text { NS } \\
\text { NS }\end{array}$ \\
\hline
\end{tabular}

action and tidal flow (i.e. the area of the enteropneust feeding experiment), and lowest in the sediments maintained in the laboratory microcosms (Table 7). The sediments from the other sites had intermediate microbial biomass. In general, growth rates per unit biomass and the mole percentage of Cluster 1 and Cluster 2 fatty acids were also greatest in sediments with highest levels of abiotic disturbance and lowest in the sediments maintained in the laboratory. The trans/cis ratios and the mole percentage of Cluster 4 fatty acids showed the opposite trend. Short-term metabolic status, the abundance of PHA, and microbial biomass assayed as phospholipid phosphate and muramic acid did not show a consistent pattern.

\section{DISCUSSION}

\section{Biotic disturbance}

In the first $2 \mathrm{~h}$ of the ray feeding experiment, shortterm metabolic status was shifted toward phospholipid synthesis, growth rates increased and microbial bio- mass was lower in the disturbed sediments compared to the ambient sediments. Several hours later, the microbial communities of the disturbed and ambient sediments showed comparable growth rates and measures of short-term metabolic status. Microbial biomass also recovered. Difficulty in observing feeding rays without disrupting their feeding made it necessary to locate fresh pits, a short but unmeasured time after feeding. In spite of this difficulty, the patterns of change in microbial biomass and activity, as well as their timing, are quite similar to those observed in the laboratory simulation of biotic disturbance (Findlay et al. 1990). A notable exception is that in the field experiment microbial growth rates in the disturbed sediments were significantly greater than those observed in the ambient sediment; in the laboratory, microbial growth rates in sieved sediments approached but never exceeded those recorded for the ambient sediments.

Many of the patterns of change in the microbial community structure induced by the disturbance of feeding rays were similar to those observed in the laboratory simulation of biotic disturbance. Aerobic microorganisms (Clusters 1 and 2) showed the greatest 
Table 7. Comparison of the microbial communities from several environmental sites and sediments maintained in the laboratory for $5 d$

\begin{tabular}{|c|c|c|c|c|}
\hline \multirow[t]{2}{*}{ Abiotic factors } & \multicolumn{4}{|c|}{ Sediments } \\
\hline & $\begin{array}{c}\text { Ambient } \\
\text { (enteropneust feeding) } \\
\text { High tidal flow } \\
\text { High wave action }\end{array}$ & $\begin{array}{c}\text { Ambient }^{\text {a }} \\
\text { (sieving disturbance) } \\
\text { Low tidal flow } \\
\text { High wave action }\end{array}$ & $\begin{array}{c}\text { Ambient } \\
\text { (ray feeding) } \\
\text { Low tidal flow } \\
\text { Low wave action }\end{array}$ & $\begin{array}{c}\text { Microcosm-5 } \mathrm{d}^{\mathrm{a}} \\
\text { (sieving disturbance) } \\
\text { No tidal flow } \\
\text { No wave action }\end{array}$ \\
\hline \multicolumn{5}{|l|}{ Measures } \\
\hline \multicolumn{5}{|l|}{ Biomass } \\
\hline TPLFA ${ }^{\mathrm{b}}$ & 36.3 & 19.3 & 12.4 & 11.2 \\
\hline $\mathrm{LPO}^{\mathrm{b}}$ & 37.9 & 52.5 & 33.1 & 47.0 \\
\hline $\mathrm{MA}^{\mathrm{b}}$ & 14.2 & 21.2 & 11.4 & 16.5 \\
\hline \multicolumn{5}{|l|}{ Growth } \\
\hline $3 \mathrm{HDNA}^{\mathrm{c}}$ & 3.0 & 1.6 & 0.8 & 0.8 \\
\hline 14 CPLFA $^{c}$ & 209.0 & 155.0 & 66.0 & 44.0 \\
\hline \multicolumn{5}{|l|}{ Nutritional status } \\
\hline 14CPLFA/14CPHA & 0.8 & 0.4 & 0.5 & 0.4 \\
\hline PHA & 5.5 & 2.3 & 5.2 & 0.3 \\
\hline 16:107 trans/cis & 0.0 & 0.08 & 0.06 & 0.35 \\
\hline 18:1 $107 \mathrm{trans} / \mathrm{cis}$ & 0.0 & 0.02 & 0.02 & 0.04 \\
\hline \multicolumn{5}{|l|}{ Community structure } \\
\hline Cluster 1 PLFA $^{d}$ & 3.6 & 2.6 & 0.0 & 0.3 \\
\hline Cluster 2 PLFA $^{\mathrm{d}}$ & 44.1 & 37.6 & 34.1 & 17.2 \\
\hline Cluster 3 PLFA $^{d}$ & 7.5 & 6.5 & 8.8 & 10.1 \\
\hline Cluster 4 PLFA $^{d}$ & 44.1 & 50.8 & 55.1 & 71.8 \\
\hline \multicolumn{5}{|c|}{ à From Findlay et al. (1990) } \\
\hline \multirow{2}{*}{\multicolumn{5}{|c|}{$\begin{array}{l}{ }^{b} \text { nmoles } \mathrm{g}^{-1} \text { dry wt } \\
{ }^{c} \text { pmoles } \min ^{-1} \text { umol }^{-1} \mathrm{LPO} 4\end{array}$}} \\
\hline & & & & \\
\hline Total mole percent & & & & \\
\hline
\end{tabular}

percentage decreases followed by the greatest percentage increases in both sieved sediments and those disturbed during ray feeding. Gram-positive, sulfatereducing, and other anaerobic bacteria (Clusters 3 and 4) were less severely affected. This comparison is complicated by an increase, during the $4 \mathrm{~h}$ of the experiment, in microbial biomass in the ambient sediments utilized as controls for the the effects of ray feeding. The greater microbial growth rates in the pit and tailings zone sediments, compared to the ambient sediments, suggests an allochthonous input of microbial biomass to the ambient sediments rather than in situ growth. Analysis of the individual PLFA data indicated that Gram-positive bacteria, sulfate-reducing bacteria, and other anaerobes disproportionately increased with this input. Low underwater visibility on the day of the experiment indicated that wave action had resuspended significant amounts of sediment and that sedimentation might be the cause of the observed increase in biomass. Initially, it appears paradoxical that sedimentation would increase these metabolic groups preferentially over aerobic bacteria, although Desulfovibrio vulgars has been routinely isolated from aerobic waters (Hardy 1981). Jørgenson (1977) demonstrated sulfate-reduction in oxidized sediments and has calculated that particles $100 \mu \mathrm{m}$ or larger in diameter could support sulfate-reduction at their centers. Laboratory simulation of biotic disturbance demonstrated the resistance of anaerobic bacteria and the susceptibility of aerobic organisms to disturbance (Findlay et al. 1990). Differential settling of large particles exposed to disturbance during resuspension may have caused both the increase in microbial biomass and the enrichment of facultative and anaerobic bacteria observed in the ambient sediments.

\section{Translocation vs predation}

The response of the microbial community to feeding by enteropneusts was similar in many ways to the response to feeding by rays. At the time of the disturbance, short-term metabolic status was shifted towards phospholipid synthesis and microbial growth rates were reduced. Several hours later, short-term metabolic status was still shifted towards phospholipid synthesis, growth rates were increasing and microbial biomass was lower in the disturbed sediments than in the ambient sediments. In contrast to physical disturbance of sediments (biotic and abiotic), predation caused an 
immediate decrease in microbial biomass. This result suggests that predation immediately removes a significant proportion of the microbial community, while simple translocative disturbances cause the death of a portion of the micrabial community that enters the detrital pool. However, this loss of microbial biomass is not detected by biochemical methods until the dead organisms decay.

\section{Food resources of Ptychodera bahamensis}

In a observational study conducted at the same site, Dobbs \& Guckert (1988) compared ambient sediments and fecal casts to determine the food resources of Ptychodera bahamensis. They considered the simplest interpretation of their data to be subtractive, that is, the differences between the ambient sediments and the fecal casts to be the results of enteropneust digestive activity. They observed that the abundance of all esterlinked, phospholipid fatty acids, except 18:107c (Cluster 2 , this study), were reduced in the fecal casts. In contrast, we found that the abundance of Clusters 1, 2 (including 18:1 $107 \mathrm{c}$ ) and 4 fatty acids were reduced in the fecal cast while Cluster 3 fatty acids (excepting 15:0) were not significantly reduced by enteropneust feeding. This would indicate that microeucaryotes, aerobic bacteria, and some anaerobic bacteria serve as the food resource of $P$. bahamensis. In addition, we noted that the mole-percent values for 2 fatty acids, i16:0 and 10Me16:0, were greater in the cast than in the ambient sediments suggesting that sulfate-reducing bacteria (Desulfobacter type) were resistant to digestion and hence selectively enriched within the microbial community of the fecal casts. It should be stressed that the fatty-acid profiles of the fecal casts from this study and the Dobbs \& Guckert study are in close agreement in terms of both absolute abundances and mole-percent values. The differences in interpretation arises from differences in the ambient sediments utilized as controls. These differences may be temporal (August [this study] vs January) or in the source of the ambient sediments. Dobbs \& Guckert collected sediment from the closest feeding depression with a spatula, while in this study, surface $(0$ to $1 \mathrm{~cm})$ sediments were collected $15 \mathrm{~cm}$ from the fecal cast with a $2.5 \mathrm{~cm}$ ID core.

\section{Importance of disturbance}

The role of disturbance in structuring the benthic microbial community can be deduced from 2 lines of evidence presented in this and the companion study (Findlay et al. 1990). First, simulated biotic disturbance, ray feeding, and enteropneust feeding all produced similar patterns of change in microbial biomass, activity and metabolic status. The effects occurred rapidly and were discernible for up to $24 \mathrm{~h}$. Myers (1977) calculated that the infaunal macrobenthos of a temperate bay process the top $1 \mathrm{~cm}$ of sediment every 0.7 to $4 \mathrm{~d}$. If these rates are typical, then the sedimentary microbial community is commonly undergoing changes induced by disturbance. Federle et al. (1983a) characterized the spatial distribution of the microbial community of a nearby (to the present study sites) subtidal sand flat. Variance components among cores in $0.2 \times 0.2 \mathrm{~m}$ clusters ranged from 16 to $55 \%$. The responses of the microbial community observed in this study to biotic disturbance may account for the large variance observed in microbial biomass and community structure. A series of random small-scale disturbances to the sediments would result in a mosaic of patches with the biomass, community structure, and metabolic activity of the microbial community being, in part, determined by recent perturbations.

The comparison of the ambient sediments at the various study sites, although a posteriori, provides the second line of evidence for the importance of disturbance in structuring the benthic microbial community. The general trend observed was that sediments receiving higher abiotic disturbance from wave action and tidal flows showed greater microbial biomass, greater rates of growth, favorable metabolic status and a higher proportion of aerobic organisms. Wave-generated hydrostatic pressure has been shown to increase water-soluble transport increasing oxygen penetration into sediments (Steele et al. 1970, Riedl et al. 1972, Webb \& Theodor 1972). Aller \& Yingst (1985) reported higher bacterial numbers and favorable metabolic status in aerobic compared to anaerobic sediments. Higher microbial biomass and favorable metabolic status have been reported around short-shoots of the seagrass Syringodium filiforme. These short-shoots interact with near-bottom flow, causing a local thinning of the layer of viscous fluid at the sediment surface and improving exchange across the surface (Thistle et al. 1984). Increased oxygen supply was believed to be responsible for the higher microbial biomass and favorable metabolic status. Enhanced harpacticoid copepod abundance around the short-shoots was attributed to the higher microbial biomass.

The response of meiofauna to mechanical sediment disturbance, as well as to predation-disturbance events has been documented (e.g. Thistle 1980, Hicks 1984). The pattern observed is similar to that observed for microorganisms. Initially, abundance is reduced at the point source of the disturbance, but recolonization occurs quickly and abundance rapidly (5 to $24 \mathrm{~h}$ ) returns to predisturbance levels. The availability of 
prey is one factor thought to control meiofaunal distribution and the rapid recolonization may be a response to the changes in the microbial community following disturbance. Experiments designed to follow both the microbial and meiofaunal communities 24 to $48 \mathrm{~h}$ following a disturbance would be needed to determine if increases in microbial biomass and metabolic activity, or some unrelated factor, is responsible for the rapid recolonization of disturbed patches by meiofauna.

The results of this study add to the increasing evidence that studies conducted using marine sediments should be designed to minimize the disturbance to those sediments (Findlay \& White 1984, Carman et al. 1989, Dobbs et al. 1989). Mixing of sediments to produce a uniform distribution of radiolabeled substrates or to reduce the variance of the natural pooulation will induce major changes in the biomass, community structure, growth rates and metabolic status of the microbial community. These changes may cause preferential radiolabeling of a portion of the microbial community and influence the availability of prey in meiofauna feeding studies.

Acknowledgements. We thank K. Carman and L. Findlay for assistance during the field portions of these studies. We appreciate helpful discussions with F. Dobbs and thank J. Guckert and S. Hacker for insightful comments on the manuscript. Drs D. Meeter and J. Ault provided guidance on the correct application of statistical procedures. This research was supported in part by grants N-0014-82-C0404 and N-0014-83K0276 from the Office of Naval Research and OCE-80-19757 from the National Science Foundation.

\section{LITERATURE CITED}

Aller, R. C., Dodge, R. E. (1975). Animal sediment relations in a tropical lagoon: Discovery Bay, Jamaica. J. mar. Res. 32: 209-232

Aller, R. C., Yingst, J. Y. (1985). Effects of the marine depositfeeders Heteromastus filiformis (Polychaeta), Macoma balthica (Bivalvia), and Tellina texana (Bivalvia) on averaged sedimentary solute transport, reaction rates, and microbial distributions. J. mar. Res. 43: 615-645

Alongi, D. M. (1985). Effect of physical disturbance on population dynamics and trophic interactions among microbes and meiofauna. J. mar. Res. 43: 351-364

Azariah, J. P., Ismail, M. M., Najib, M. A. (1975). Investigation on the ecology and respiratory responses of the hemichordate Ptychodera flava to tidal cycles and salinity changes. Biol. Bull. mar. biol. Lab., Woods Hole 149: 455-466

Brown, B. Wm., Jr, Hollander, M. (1977). Statistics: a biomedical introduction. John Wiley and Sons, New York

Carman, K. R., Dobbs, F. C., Guckert, J. B. (1989). Comparison of three techniques for administering radiolabeled substrates to sediments for trophic studies: uptake by meiofauna. Mar. Biol. 102: 119-125

Carman, K. R., Thistle, D. (1985). Microbial food partitioning by three species of benthic copepods. Mar. Biol. 88: $143-148$
Dobbs, F. C., Guckert, J. B. (1988). Microbial food resources of the macrofaunal-deposit feeder Ptychodera bahamensis (Hemichordata: Enteropneusta). Mar. Ecol. Prog. Ser 45: $127-136$

Dobbs, F. C., Carman, K. R., Guckert, J. B. (1989). Comparison of three techniques for administering radiolabeled substrates to sediments for trophic studies: incorporation by microbes. Microb. Ecol. 17: 237-250

Federle, T W., Hullar, M. A., Livingston, R. J., Meeter, D. A., White, D. C. (1983a). Spatial distribution of biochemical parameters indicating biomass and community composition of microbial assemblies in estuarine mud flat sediments. Appl. environ. Microbiol. 45: 58-63

Federle, T. W., Livingston, R. J., Meeter, D. A., White, D. C. (1983b). Modification of estuarine sedimentary microbiota by exclusion of epibenthic predators. J. exp. mar. Biol. Ecol. 73: 81-94

Findlay, R. H., Pollard, P. C., Moriarty, D. J. W., White, D. C. (1985). Quantitative determination of microbial activity and community nutritional status in estuarine sediments: evidence for a disturbance artifact. Can. J. Microbiol. 31: 493-498

Findlay, R. H., Trexler, M. B., Guckert, J. B., White, D. C. (1990). Laboratory study of disturbance in marine sediments: response of a microbial community. Mar. Ecol. Prog. Ser. 62: 121-133

Findlay, R. H., White, D. C. (1984). In situ determination of metabolic activity in aquatic environments. Microbiol. Sci. 1: 90-95

Grime, J. P. (1977). Evidence for the existence of three primary strategies in plants and its relevance to ecological and evolutionary theory. Am. Nat. 111: 1169-1194

Hardy, J. A. (1981). The enumeration, isolation and characterization of sulfate reducing bacteria from North Sea waters. J. appl. Bacteriol. 51: 505-516

Hargrave, B. T. (1970). The effect of deposit-feeding amphipods on the metabolism of benthic microflora. Limnol. Oceanogr. 15: 21-36

Hicks, G. R. F. (1984). Spatio-temporal dynamics of a meiobenthic copepod and the impact of predation-disturbance. J. exp. mar. Biol. Ecol. 81: 47-72

Higa, T., Sakemi, S. 1. (1983). Environmental studies on natural halogen compounds. 1. Estimation of biomass of the acorn worm Ptychodera flava (Hemichordata, Enteropneusta) and excretion rate of metabolites at Kattore Bay, Kohama Island, Okinawa, Japan. J. chem. Ecol. 9: 495-502

Hollander, M., Wolfe, D. A. (1973). Nonparametric statistical methods. John Wiley and Sons, New York

Hylleberg, J. (1975). Selective feeding by Abarenicola pacifica with notes on Abarenicola vagabunda and a concept of gardening in lugworms. Ophelia 14: 113-137

Jørgensen, B. B. (1977). The sulphur cycle of a coastal marine sediment (Limfjorden, Denmark). Limnol. Oceanogr. 22: 814-832

King, G. M. (1986). Inhibition of microbial activity in marine sediments by a bromophenol from a hemichordate. Nature, Lond. 323: 257-259

Kneib, R. T. (1985). Predation and disturbance by grass shrimp Palaemonetes pugio Holthuis, in soft-substratum benthic invertebrate assemblages. J. exp. mar. Biol. Ecol. 93 91-102

Livingston, R. J., Sheridan, P. S., McLane, B. G., Lewis, III, F. G., Kolylinski, G. G. (1976). The biota of the Apalachicola Bay system: functional relationships. In: Proc. Conf. Apalachicola Drainage System, Florida Marine Research Publication 26, p. 75-100

Myers, A. C. (1977). Sediment processing in a marine subtidal 
sandy bottom community. 1. Physical aspects. J. mar. Res 35: 609-632

Neter, J., Wasserman, W., Kutner, M. H. (1985). Applied linear statistical models. Richard D. Irwin, Inc., Homewood, Illinois

Newell, R. (1965). The role of detritus in the nutrition of two marine deposit feeders, the prosobranch Hydrobia ulvae and the bivalve Macoma balthica. Proc. Zool. Soc. Lond. 144: $25-45$

Oliver, J. S., Kvitek, R. G., Slatter, P. N. (1985). Walrus feeding disturbance: Scavenging habitats and recolonization of the Bering Sea benthos. J. exp. mar. Biol. Ecol. 91: 233-246

Orth, R. J. (1975). Destruction of eelgrass, Zostera marina, by the cownose ray, Rhinoptera bonasus in the Chesapeake Bay. Chesapeake Sci. 16: 205-208

Rees, E. I. S., Nicholaidou, A., Laskaridou, P. (1977). The effects of storms on the dynamic of shallow water benthic associations. In: Keegan, B. F., Ceidigh, P. O., Boaden, P. J. S. (eds.) Biology of benthic organisms. Pergamon Press, New York, p. 465-474

Reichardt, W. (1988). Impact of bioturbation by Arenicola marina on microbiological parameter in intertidal sediments. Mar. Ecol. Prog. Ser. 44: 149-158

Reidenauer, J. A., Thistle, D. (1981). Response of a soft-bottom harpacticoid community to stingray (Dasyatis sabina) disturbance. Mar. Biol. 65: 261-267

Riedl, R. J., Huang, N., Machan, R. (1972). The subtidal pump: a mechanism of interstitial water exchange by wave action. Mar. Biol. 13: 210-221

Sherman, K. M., Reidenauer, J. A., Thistle, D., Meeter, D. (1983). Role of a natural disturbance in an assemblage of

This article was presented by Dr S. Y. Newell, Sapelo Island, Georgia, USA marine free-living nematodes. Mar. Ecol. Prog Ser. 11: $23-30$

Steele, J. H., Munro, A. L. S., Giese, G. S. (1970). Environmental factors controlling the episammic flora on beach and sublittoral sands. J. mar. biol. Ass. U. K. 50: 907-918

Thistle, D. (1980). The response of a harpacticoid copepod community to a small-scale natural disturbance. J. mar. Res. 38: 381-395

Thistle, D., Reidenauer, J. A., Findlay, R. H., Waldo, R. (1984). An experimental investigation of enhanced harpacticoid (Copepoda) abundances around isolated seagrass shoots. Oecologia (Berl.) 63: 295-299

Van Blaricom, G. R. (1977). Preliminary observations and interactions between two bottom-feeding rays and a community of potential prey in a sublittoral sand habitat in Southern California. In: Simenstad, C. A., Lipovsky, S. J. (eds.) Fish food habits studies. Washington Sea Grant, Seattle, p. 153-162

Webb, J. E., Theodor, J. L. (1972). Wave induced circulation in submerged sands. J. mar, biol. Ass. U. K. 52: 903-914

Woodin, S. A. (1978). Refuges, disturbance, and community structure: a marine softbottom example. Ecology 59: $274-284$

Woodin, S. A. (1981). Disturbance and community structure in a shallow water sand flat. Ecology 62: 1052-1066

Yingst, J. Y., Rhoads, D. C. (1980). The role of bioturbation in the enhancement of bacterial growth rates in marine sediment. In: Tenore, K. R., Coull, B. C. (eds.) Marine benthic dynamics. Univ. of South Carolina Press, Columbia, p. $407-421$

Manuscript first received: May 25, 1989

Revised version accepted: January 4, 1990 